\title{
Power and Innovation: Excavating pre-1806 Steam Engines in the Manchester Area
}

\section{Introduction}

\section{Dr Michael Nevell, University of Salford}

\author{
Submitted and accepted text, May 2018, for The International Journal of the History of \\ Engineering and Technology, volume 88, Issue 2 (2018).
}

The survival of any early stationary steam engine is exceptional, as is the archaeological investigation of these sites and the discovery of contemporary engine parts. Perret lists seven Newcomen pumping colliery pumping engines surviving in various states of completeness from the period 1725 to 1800 (Perrett 2012). The number of rotative Boulton and Watt engines that survive from before 1800 is equally small (examples can be seen at the Power House Museum in Sydney from 1785; National Museums Scotland from 1786; Science Museum in London from 1788; and the Henry Ford Museum in Dearborn, USA, from 1788; (Hulse 2001). Nor are there many more $18^{\text {th }}$ century engine houses surviving as upstanding monuments. Bick listed sixteen pre-Cornish beam engine houses surviving from the $18^{\text {th }}$ century in Britain, although there may well be more, unrecognised due to later alteration or domestic conversion (Bick 1999, 134-135).

In contrast, estimates, based upon secure documentary and archaeological evidence, suggest that at least 2191 stationary steam engines were built during the $18^{\text {th }}$ century in Britain with 173 known from historic Cheshire and Lancashire (Kanefsky \& Robey 1980; Kanefsky this volume; Nuvolari et al 2011). Of these engines 451 were built by Boulton and Watt (of which 268 were rotative types) (Tann 1981). This number could be considerably larger, although the figures are confused by poor contemporary descriptions and by the frequent re-use of engines and engine parts (Kanefsky \& Robey 1980).

Archaeological fieldwork has the ability to both add to the number of known early steam engine sites derived from documentary sources and to highlight the physical evidence for the diffusion of this technology. This paper will focus upon the archaeological excavation of nine steam engines from six sites in the Manchester area spanning the period c. 1775 to 1805 (Nevell 2008; 82-92; Miller \& Wild 2007; Miller \& Glithero 2016). It will characterize the remains recovered at each site, discussing the evidence for technological innovation and craft production, before concluding with a summary of the ways in which industrial archaeology can help in understanding the development and spread of early steam engine technology especially in the context of the textile mill.

\section{Excavating early steam engines in Manchester}

One the few areas where there has been a systematic attempt to investigate early steam engine sites archaeologically is Manchester. This town had the second largest concentration of Boulton and Watt steam engines in 1800, at 44 engines, after London (with 54) (Kanefsky \& Robey 1980). These were installed in cotton spinning mills and at textile finishing sites across the city. At least a further dozen engines were built and installed in Manchester mills by other manufacturers, mostly the Salford engineers Bateman and Sherratt who were 
working in the 1790s on Newcomen and Boulton and Watt hybrid designs. Hunt of London is also known to have supplied Newcomen-hybrid engines to Manchester mill owners for pumping.

At the end of the 1990s a conscious decision was made by the city's planning archaeologists to actively record, during the redevelopment of central Manchester after the IRA bomb damage of 1996, the industrial archaeology of the $18^{\text {th }}$ and $19^{\text {th }}$ century city and its region (Redhead 2011, 53-54). With the guidance of the local planning archaeologists such developer-funded excavations have been focused upon the mill power systems: wheel pits, steam engine houses and boiler houses (Nevell 2016). These were the main technological areas that could be recovered archaeologically, and which saw rapid phases of development during the late $18^{\text {th }}$ to early $20^{\text {th }}$ centuries. Thus, they help to reveal the biography of the building under investigation. The wider mapping of technological and spatial changes across Greater Manchester has focused attention upon issues such as the local introduction of new $18^{\text {th }}$ century mill sites, the introduction of the first steam powered textile mills, the fate of water-powered mills, and the social control of the workforce on these sites (Nevell 2010, 153156). Such targeted excavation, as well as standing building recording, through the planning process has also encompassed all the major branches of the textile industry in the region; cotton, silk and wool spinning, weaving and finishing mills.

\section{Colliery pumping - the city region's first steam engines}

The oldest steam engine site to be investigated archaeologically in the Manchester city region is also one of the oldest and most famous $18^{\text {th }}$ century steam engines. Fairbottom Bobs (SD 9357 0200) was a Newcomen-type atmospheric engine used to pump water, via a force pump, from the Fairbottom Colliery Company's mine in the Medlock valley north of Ashton-underLyne. It was built in the period 1764 to 1776 and ceased working around 1826. After lying abandoned for 103 years the ruinous engine was sold to Henry Ford, dismantled and moved to the USA, after partially excavating the site and recovering the steam inlet valve, ' $Y$ ' actuator, sliding rods, piping and other engine parts. The heavily restored steam engine is currently on display at the Dearborn Museum in Michigan, USA (Nevell \& Roberts 2003, 5762). Further archaeological excavation was undertaken in 1982 and again in 1999 and 2000, when the whole site was stripped and the adjacent cottage excavated.

These remains, which include not just the engine but also the boiler house and associated cottages and stables, lie on the northern bank of the River Medlock on a terrace $108 \mathrm{~m}$ above sea level, and c. $2 \mathrm{~m}$ above the present level of the river. Excavations in 1999-2000 exposed the remains of several structural elements associated with the beam engine. Guided by the standing remains of the chimney and the records of the 1982 excavation by MRIAS, work in 1999 and 2000 revealed substantial remains of all the key structures associated with the beam engine. These included remains of the cylinder bay, beam wall, ash pit, drains, the boiler walls, and floor. As with many early engines it does not appear that the beam engine was in a roofed structure (Nevell, Roberts \& Champness 2004). The key elements of the engine supports and boiler house were built in the same style using local gritstone and fine ashlar blocks. The cylinder bay measured $1.75 \mathrm{~m} \times 3.20 \mathrm{~m}$ and survived up to 10 courses or $2 \mathrm{~m}$ deep. When the engine was dismantled in 1929 the records show that the cylinder had a diameter of $28 \mathrm{in}$. The chimney base, boiler house, and stone drain running to the east of the site towards the river 
Medlock, the subject of brief examination in 1929, were fully excavated in 1999-2000. These features appear to be contemporary with the cylinder bay and beam wall. The site of the boiler lay immediately east of the cylinder bay in an area of brick flooring $2 \mathrm{~m} \times 3.3 \mathrm{~m}$. Only the ash pit was investigated in 1929. Full excavation of the boiler area revealed that part of the walling around this area was curved, probably because it was originally built around a domed, circular, or haystack boiler. This was replaced by a wagon boiler.

The most recent excavations revealed two significant phases of activity on the site. All the major elements of the beam engine (the hay stack boiler, chimney, cylinder pit and beam wall) were constructed at the same time, possibly as early as $1764 / 5$. It was certainly operating in the 1770s as indicated by the excavation of the iron chisel from the ash pit which bore the date of ' 1776 '. Later, there were major alterations to the site of the boiler when the hay stack boiler was replaced by a wagon boiler with a large brick-lined ash pit, flues and chimney. There were also major alterations to the engine itself, including new valves and steam pipes associated with the cylinder, as recovered in 1929. Taken together these changes represented a considerable investment, probably in an attempt to modernise and extend the working life of the engine. It seems likely that this refurbishment was the outcome of the request of the Fairbottom Colliery Company for money from the Ashton Canal Company towards restoration and repair of the beam engine in 1801 (Nevell, Roberts \& Champness 2004).

The more fragmentary remains of a late $18^{\text {th }}$ century colliery pumping engine were excavated in 1999 a few kilometers to the south at Glass House Fold, Haughton Green, on the western bank of the River Tame (SJ 940 946). This was probably the site of the 'water engine built for Mr Hyde Clarke' noted in 1795 (Aikin 1795, 457) and shown on Johnsons' map of Manchester in 1819. The site is also shown on the Haughton tithe map from 1845 (the site being owned at that point by Edmund Hyde Clarke; LRO DRM 1/50).

The excavated remains of Haughton colliery, as it was called in 1819 (although it was later known as Glass House Colliery) comprised two buildings, sitting side by side. The more westerly, pumping engine house, was a square structure measuring $5 \mathrm{~m}$ by $5 \mathrm{~m}$. This building had substantial stone walls between $1.10 \mathrm{~m}$ and $1.40 \mathrm{~m}$ wide which were bonded with a hard, white, gritty mortar. Protruding from the north wall were three iron rods, possibly associated with the beam engine that stood within this building. The second building, which lay adjacent to the south-east, was $3.80 \mathrm{~m}$ wide and $6.4 \mathrm{~m}$ long with stone walls $1.28 \mathrm{~m}$ wide at the western and southern ends and a southern side wall $0.40 \mathrm{~m}$ wide. The northern wall did not survive. This building was interpreted as a boiler house (Nevell \& Walker 1999, 36-37). The steam engine appears to have been carefully dismantled, along with the engine house, when the colliery closed in the mid- $19^{\text {th }}$ century. The site may have been superceded by Hulmes Pit (SJ 925 937; $1.5 \mathrm{~km}$ to the south-west), where a third colliery pumping engine dating from c. 1834 was excavated in the 1970 s.

\section{Steam Power in Manchester Textile Mills, 1781 to 1800}

Manchester was not the first location to successfully use steam power to assist in textile manufacture; Richard Arkwright used a pumping engine to back-pump water from the tail race to the reservoir for a waterwheel at Haarlem Mill in Wirksworth, Derbyshire, around 
1780. The city wasn't even the setting for the first use of Boulton and Watt's rotative engine arrangement to power directly textile machinery; that was Papplewick Mill in Nottinghamshire in 1786 (Menuge 1993, 50-52). Yet, by 1800 Manchester had become the centre of steam-powered cotton spinning in Britain through a combination of the ready availability of cheap coal, easily accessible capital and a willingness amongst its entrepreneurial class to take risks in using cutting-edge technology to improve their profits.

From having no textile mills in 1780 Manchester became the largest mill town in the world, with 33 working textile spinning mills in 1800, 86 working in 1831 and 108 working in 1850. Other industries such as engineering, iron and glass making also flourished in the mid-19 ${ }^{\text {th }}$ century with hundreds of factory sites recorded in 1850. This phenomenal industrial rise was matched by its spectacular population growth in the first half of the $19^{\text {th }}$ century; Manchester nearly doubled its size between 1801 and 1821 from 75,281 to 126,066 people, and then more than doubled its population by 1851 , when there were 303,382 people within the new borough (Hartwell 2001, 17; Kidd \& Wyke 2016).

172 textile mill sites are known from within the boundaries of the $21^{\text {st }}$ century city of Manchester. These were built between 1781 (Arkwright's Mill on Miller Street) and 1924 (W H Holland \& Sons cotton spinning mill in Miles Platting (Williams with Farnie 1992, 18-21). 42 mills survive within the boundaries of the city as of May 2018, although these are not representative of the chronological spread, construction, and motive power of the city's mills as a whole (Nevell 2008). However, excavation work has begun to remedy this imbalance and in doing so has revealed evidence for the first generation of steam-powered Manchester textile spinning mills. This includes arguably the two most important textile mills of this earliest period: Richard Arkwright's Shudehill Mill of 1781-3 and A \& G Murray's Mills, in Ancoats, of 1798-1806 (Miller \& Glithero 2016; Miller \& Wild 2007).

\section{The Steam Engines of Arkwright's Shudehill Mill 1782 to 1799}

Richard Arkwright's Shudehill Mill, built in the years 1781-83, was Manchester's first purposebuilt cotton spinning factory. It was established as a partnership, with Arkwright working with William Bricklebank, John Simpson, Samuel Simpson, and John Whittenbury. The five-storey, $218 \mathrm{ft}(66 \mathrm{~m})$ long, brick-built, mill was designed to contain water-frame cotton spinning machines. Although there are no direct figures to indicate the cost of building and equipping the structure, in 1784, when Arkwright sold his share to his son, it was insured for $£ 3,000$ and the machinery for another $f 1,000$, a figure which rose to $f 5000$ the following year. The site was destroyed in the Manchester Blitz of 1940 and has since been used as a car park, but in September 2005 the Channel 4 archaeology television programme Time Team relocated this iconic site and in 2014 and 2015 Oxford Archaeology North completely excavated the site prior to construction work (Miller \& Glithero 2016, 98). The earliest plan of the mill can be found on Charles Laurnet's map of Manchester, published in 1793. This shows the mill surrounded by a series of reservoirs. Annotation confirms the location of a central wheelhouse housing a waterwheel, although it is unclear from this evidence how the water system worked.

The archaeological investigations revealed evidence for three of the five steam engines installed on the site between 1782 and 1799 (Miller \& Glithero 2016, 102-111). Contemporary 
accounts record that Arkwright's Mill was the first in Manchester to use steam-power (Chaloner 1954, 90-1) and there is some evidence to suggest that Arkwright tried initially to run his water-frames directly from an atmospheric steam engine (Aspin 2003, 72-3). The local historian James Ogden wrote in 1782 that "Mr Arkwright's machines are setting to work by a steam engine, for carding and spinning cotton. The erection of the mill chimney attracts crowds daily, its height being a source of wonder and not a little misgiving. The mill was turned by water-power, the water being obtained from Shudehill pits, while the engine was used to pump water to a higher level" (Ogden 1783). This comment is somewhat contradictory but does suggest that some of the mill machinery may originally have been powered by steam. There is some correspondence between Arkwright and James Watt on the matter from 1781 (Aspin 2003, 72). According to the Boulton and Watt papers the first mill engine at Arkwright's Mill was an atmospheric engine designed by Thomas Hunt (Tann 1981). Hunt specialized in producing atmospheric steam engines with a crank and flywheel. A handbill from 1783 claimed that Thomas Hunt of London had erected 22 such rotative steam engines, including two for Richard Arkwright in Manchester (Birmingham Central Library, Boulton and Watt MSS, Muirhead IV, Misc.). It is thus possible that one of these engines ran some of the machinery at Arkwright's Mill on Shudehill, although why it failed is unknown although Miller and Glithero have noted that 'cotton spinning demanded a constant turning force and Hunt's wooden flywheel would not have steadied the engine sufficiently' (Miller \& Glithero 2016, 103). Archaeologically, no direct remains of this first power system survived. However, the absence of positive archaeology suggests that the engine and boiler lay outside the mill near the middle of the eastern wall, where the later engines lay and have no doubt removed the evidence.

The archaeological work did though reveal evidence for the waterwheel and returning engine arrangement that formed the second phase power development at the mill. This included the remains of the boilers and engine, including the substantial brick foundations of the northern wall of the engine house, east of the mill and opposite the wheel pit. A $2.9 \mathrm{~m}$ length of flue to the north of this wall and part of the well that had been placed between the engine cylinder and pump barrels were also found (Miller \& Glithero 2016, 104). The wheel pit survived largely intact and provided to be a primary feature, integral to the original mill design. This feature was $28 \mathrm{ft}$ by $8 \mathrm{ft}(8.53 \mathrm{~m}$ by $2.44 \mathrm{~m})$ wide and survived up to $7.9 \mathrm{~m}$ deep. The location of the waterwheel axle was evident in the elevations of the wheel pit as $1.3 \mathrm{~m}$-wide openings. Miller and Glithero suggest that the gap between the base of the $28 \mathrm{ft}$ diameter waterwheel and the bottom of the wheel pit, at $7 \mathrm{ft}(2.21 \mathrm{~m})$ would have acted as a sump from which the water was pumped. Excavation revealed five openings at the base of the wheel pit's eastern wall, providing a conduit for the water to pass through the wall of the mill towards the pumps. Two large arched channels in the western wall of the wheel pit probably allowed water from the lower reservoir to enter the wheel pit, ensuring a constant level of water in the bottom of the wheel pit (Miller \& Glithero 2016, 104). A small brick-lined pit west of the water wheel marked the position of the pit wheel and the housing for the horizontal bevel gear that would have driven the shafts along the centre of the mill, with vertical shafting providing power to the upper floors. The precise date of installation of this system is not clear, though it must have been around 1783 before Arkwright sold the mill to his son Richard in 1784 . The system was described in 1788 and is recorded on a Boulton and Watt drawing from 1789 surveyed ahead of replacing the waterwheel and returning engine (Miller and Glithero 2016, 104-105). This indicates that the cast-iron pump barrels were each 30in $(0.76 \mathrm{~m})$ across and were situated 
$6 \mathrm{ft}(1.83 \mathrm{~m})$ east of the waterwheel. The beam was $23 \mathrm{ft}(7 \mathrm{~m})$ long and pivoted on a substantial wall.

Three more steam engines were installed on the site during the 1790s. These were requested and paid for by John and Samuel Simpson who had bought the complex in 1786. The first of these was a steam engine installed in a new spinning block facing Miller Street. This was a $6 \mathrm{hp}$ Boulton and Watt 'sun and planet' engine supported on wooden framing and was erected in 1791. This was replaced in 1799 by a much larger sun and planet engine of 40hp with steam supplied by two wagon boilers. The site of these two engines was not excavated. However, the site of the third engine, installed in 1792 in the original 1781-83 Arkwright Mill, was investigated (Miller \& Glithero 2016, 108-10). The drawings and notes for the 1792 engine called for a double-acting engine of $40 \mathrm{hp}$ with a 31.5 inch by $7 \mathrm{ft}$ cylinder $(0.8 \mathrm{~m}$ by $2.14 \mathrm{~m})$ with sun and planet gearing. The beam cylinder and pivot were supported on masonry. Excavation revealed the southern wall of the $3.35 \mathrm{~m}$ by $3.35 \mathrm{~m}$ engine house, abutting the eastern wall of the mill opposite the wheel pit. A $1.1 \mathrm{~m}$-wide brick wall lay across the centre of the engine house and represented the foundation for the lever wall. Furthermore, excavation confirmed that the waterwheel had been removed and the wheel pit adapted to accommodate the flywheel and bearings for the new engine (Miller \& Glithero 2016, 109). The two $16 \mathrm{ft}$ by $7 \mathrm{ft}$ $(4.88 \mathrm{~m}$ by $2.13 \mathrm{~m})$ wagon boilers supplying steam to the engine were situated further to the east and excavation located the two flues associated with these running from the rear of eastern wall of the boiler house. These were channels $0.3 \mathrm{~m}$ made from handmade brick and led to a chimney on the upper terrace, $30 \mathrm{~m}$ to the east. An earlier flue leading from the $1 \mathrm{~m}$ thick walls of the chimney (which survived to a depth of nearly $4 \mathrm{~m}$ ) suggested that it may have been re-used from the one that served the 1780 s returning engine.

\section{Early Mill Power Systems on Shooters Brook}

Two mid-1780s cotton mills built on Shooters Brook in the Ancoats suburb (Chapman 1981; Nevell 2003, 40), both excavated in 2005 by Oxford Archaeology North, also revealed evidence for early steam power systems.

Excavation revealed the remains of a small brick structure of $22 \mathrm{~m}$ by $11 \mathrm{~m}$ that straddled the brook and was built in the late 1780s. The evidence for the primary water power system was very fragmentary and comprised only the remains of a large culvert, which ran along the eastern bank of the brook towards the eastern end of the mill (Miller \& Wild 2007, 35-6). Around 1791 documentary evidence indicates that a steam-powered pumping engine was installed in order to guarantee a constant supply of water for the wheel (Hills 1970,141). This seems to have been a steam engine built by the local Manchester engineer Joshua Wrigley, producing roughly $20 \mathrm{hp}$ that serviced a water wheel of 12 feet in diameter $(3.66 \mathrm{~m})$. Unfortunately, neither the wheel pit nor the engine house survived at Salvin's Factory, although a secondary culvert was located at the eastern end of the mill that appears to have been associated with this phase of the mill (Miller \& Wild 2007, 36). Wrigley's system was a development of a pumping engine patented by Thomas Savery in 1698 which comprised a pair of vessels into which steam was admitted alternately. The steam was condensed in turn in each vessel creating a partial vacuum which forced water into one and then the other vessel creating the pumping action (Farey 1827, 99). Wrigley adapted this pump, increasing the power by adding a wagon boiler and arranging the mechanism so that the water was pumped 
by atmospheric pressure from a lower reservoir to a higher reservoir from where it fell directly onto a wheel, thereby creating an overshot waterwheel. As Miller and Wild have noted "it was cheap to build as it did not require the precision engineering demanded by machines comprising a piston and accurately bored cylinder, and no premiums were charged for its use" (Miller \& Wild 2007, 45).

The Wrigley system of steam pumping engine and waterwheel provided, at $£ 200$ in 1790 for the whole system (Tann 1970, 122), a cheap technological bridge between the waterpowered water-frames developed by Richard Arkwright and the new rotary beam engine that came to power the mule-spinning machine, that later typified the Manchester textile mill. When James Watt junior visited Manchester in March 1791 he noted that Wrigley had "orders for 13 engines for this town and neighbourhood, all of them intended for working cotton machinery of one kind or other" (Musson \& Robinson 1969, 403). Nor was this arrangement to be found only in Manchester; in Yorkshire at least 35 mill sites were using pumping engines by 1800 (Giles \& Goodall 1992, 133).

In 1796 this pumping engine was replaced by a $25 \mathrm{ph}$, double-acting, Boulton and Watt beam engine. It was housed in a new building $14 \mathrm{~m}$ by $6 \mathrm{~m}$ in plan at the north-western end of the mill. Excavation revealed that the room was divided into two spaces with the boiler room at the eastern end (Miller \& Will 2007, 36-38). All that survived of this 1796 engine was an ashlar block from the engine house floor that incorporated two metal rods protruding from its upper surface.

The second Shooter's Brook mill to be adapted for steam power in the 1790s was New Islington Mill. These excavations revealed a factory $30 \mathrm{~m}$ long and $15.25 \mathrm{~m}$ wide and aligned with its eastern gable to the brook. The powerhouse was at this end of the mill structure. In its first phase the mill was water powered. Around 1799 steam engine was added to the power system, the original wheel pit being largely destroyed by its insertion (Miller \& Wild 2007, 41-2).

This beam engine was insured by Jesse Hirst in 1799 for $£ 120$ and the associated millwright works for $f 80$ (Royal Exchange 7253/169411). Whilst the documentary evidence did not specify the type or form of steam engine, and Hirst does not occur as a Boulton and Watt customer in their archives, archaeological evidence shows that this was a beam engine. This was housed in a purpose-built engine house $14.5 \mathrm{~m}$ by $6.8 \mathrm{~m}$ in plan. It was divided into two areas by a brick wall. The northern area contained the beam engine. Several square-sectioned iron rods, that had been used to restrain the engine cylinders and framing, were found protruding vertically through the bench walls on which the engine sat. Worn recesses on the inner face of the engine-house walls, and small evenly-spaced square sockets within the upper course probably related to the timber engine frame. The engine-room floor was built of bricks, flagstones and ashlar blocks. The ashlars, which were located along the eastern edge of the floor, supported a large iron plate that sealed an earlier culvert that ran underneath engine house. A cast-iron pipe $0.16 \mathrm{~m}$ across internally, protruded through the bench wall and finished by this plate. This probably represented the main steam pipe from the boiler to the engine. The boiler occupied the other end of the engine house beyond the partition. The culvert had been blocked-off at the eastern end of the engine house to form a pit $1 \mathrm{~m}$ square and was probably used as a water tank for condensing purposes (Miller \& Wild 2007, 42-44). 
Miller and Wild suggest that this beam engine was probably built likely, perhaps by Bateman and Sherratt, the leading local engine manufacturers in the late $18^{\text {th }}$ and early $19^{\text {th }}$ centuries Miller \& Wild 2007, 42). One oddity of the later power arrangement was that when around 1815 additional power was added, this took the form of a previously unrecorded waterwheel and Wrigley steam-pumping engine. Why such an antiquated power-system was used in the late 1810 s is unclear (Miller \& Wild 2007, 44-45).

\section{Murrays Mills Steam Engines, 1798 to 1806}

The mills of $A \& G$ Murray lie in the industrial suburb of Ancoats and are the oldest surviving mill complex in Manchester (Rose with Falconer \& Holder 2011, 11-32). This large courtyard complex is bounded by Murray Street to the west and Bengal Street to the east. It was built in three phases between 1798 and 1806 (Williams with Farnie 1992, 159-63). Archaeological work by Oxford Archaeology North during the extensive renovation of the complex in the mid2000s, and in 2018 by the University of Salford, recorded the remains of two of the original three steam engine locations.

The earliest mill block on the site, Old Mill, faces Redhill Street (the Phase 1 building built between 1798 and 1801). Attached to the east is Decker Mill (the Phase 2 part of the complex built between 1801 and 1804). The building of this block necessitated the construction of a new engine house and power transmission system for the Old Mill. The New Mill on Jersey Street and two narrower blocks known as the Murray Street Block and the Bengal Street Block completed the courtyard complex (Phase 3, 1804-17; Miller \& Wild 2007, 95-116). These earliest phases of construction, and the history of $A \&$ \& Murray Limited, reflected the welldocumented sequence of booms and slumps in the cotton trade between c. 1790 and c. 1820, the period when Manchester emerged as a major industrial and commercial centre.

Murrays Mills was the largest and one of the most innovative mill complexes in Manchester. Not only did it make extensive use of steam power in buildings, some of which were eightstoreys high, but the four multi-storey blocks were built around an enclosed canal basin linked to the Rochdale Canal by a tunnel running beneath Union Street. The addition of this canal basin after the Rochdale Canal opened past the mill in 1804 foreshadowed one of the characteristic features of later mill location in Manchester; access to an adjacent canal arm. The spinning blocks themselves had timber floors supported by cast-iron columns of cruciform cross-section and the two larger blocks (Old and Decker Mills and New Mill) were powered by separate Boulton and Watt beam engines via centrally-placed upright shafts.

Whilst the spinning blocks from Phases 1 to 3 survive, the $179812 \mathrm{hp}$ steam engine located on the eastern gable of the Old Mill was removed when Decker Mill was built. The floor of the new 1801 engine house on the northern side of the enlarged mill was largely destroyed by the building of an economizer on the site in the late nineteenth century. However, the northern elevation of the 1801 engine house has survived. This contains fragments of the original structure associated with the 40hp steam engine including sandstone blocks to support the frame, or entablature, around the top of the beam engine; a sandstone axle mounting; and two blocked arched windows. The northern wall of the external stair tower contains a timber lintel or sole plate that supports a cast-iron bearing box that housed the 1801 drive shaft running into the mill via this stair tower (Miller \& Wild 2007, 104-107). In 
both Old Mill and Decker Mill cast-iron fittings and empty sockets mark the original position of the two vertical drive shafts that ran Old Mill and Decker Mill, and the branching horizontal line shafting arrangement, from which the belts drove the cotton spinning mule machinery on the upper floors. These can be seen in bay three of Old Mill and bay 18 of Decker Mill (Miller \& Wild 2007, 108-115).

The New Mill block built along the southern side of Jersey Street in 1804-06 was an innovative structure. It matched the height of Old Mill and Decker Mill, at eight-storeys, but was longer and wider than both (195ft by $46 \mathrm{ft}$ or $59.5 \mathrm{~m}$ by $14 \mathrm{~m})$. It had a total floor area of $6,664 \mathrm{~m}^{2}$, more than the combined floor areas of Old Mill $\left(3,328 \mathrm{~m}^{2}\right)$ and Decker Mill $\left(3,204 \mathrm{~m}^{2}\right)$. The engine house, which still survives, contained a $45 \mathrm{hp}$ engine, the stone foundations for which were excavated during the renovation work in 2018, and a square chimney, which is the earliest mill chimney to survive within the city. Remains of the power distribution system within the engine included a framing for the vertical drive shaft does survive on the fourth floor in bay 10 , one of four that rose through the mill and ran the horizontal line shafting and belt drive system (Miller \& Wild 2007, 108-13).

\section{Conclusion}

Of the nine early steam engines excavated in the Manchester area between 1999 and 2018, spread across six sites, seven powered cotton spinning mills and two were mine pumping engines. Of these sites, two have extensive, though often contradictory, documentary material associated with them (Arkwright's Shudehill Mill and Murray's Mills). The other four sites had only fragmentary documentary material available. The recovery of technical information regarding the remains of the steam engines and their associated boilers, and the detailed development of each site, was only possible through archaeological excavation.

It is now clear that excavating early mill engine sites and mining pumping engine sites can help in understanding both the development of individual site power systems and the rate of adoption of early steam technology. At the very least archaeological fieldwork can confirm the precise location and arrangement of steam engines previously identified from documentary research. Detailed examination of such sites, once located, can highlight the reality of early craft steam engine building. This was usually undertaken using local skilled labour and often resulted in engine designs being adapted to their local circumstances. This kind of fieldwork can also demonstrate the rapid technological changes in engine design on a particular site. This reflects both the developments in steam engine design of the period and the increasing demands of certain industries, such as textile production, for ever larger amounts of power. Archaeological excavation is also a way of recovering in situ elements of early steam engine technology, often not documented in the historical record for that individual site, and demonstrating the longevity of earlier technology.

The archaeological approaches outlined in this paper provide another way of understanding the, often rapid, technological development of the individual power systems on these sites. They also also underline the variety of ways in which steam power was adopted in the period c. 1775 to 1805 , demonstrating the rapid diffusion of this technology. 


\section{Bibliography}

Bick, D., 1999, 'Evolution of the Pre-Cornish Beam Engine House', Industrial Archaeology Review 21.2, 117-36.

Chaloner W H, 1954, 'Peter Drinkwater and the Early Factory System in Manchester 17881800 ', Bulletin of the John Rylands Library 37, 78-102.

Hulse D, 2001, The Development of Rotary Motion by Steam Power. TEE Publishing, Leamington Spa.

Kanefsky, J. W. \& Robey, J., 1980, 'Steam engines in eighteenth-century Britain: A quantitative assessment', Technology and Culture 21:2.

Kidd A \& Wyke A, eds., 2016, Manchester. Making the Modern City. Liverpool University Press.

Menuge A, 1993, 'The Cotton Mills of the Derbyshire Derwent and its Tributaries', Industrial Archaeology Review 16.1, 38-61

Miller I \& Glithero J, 2016, 'Richard Arkwright's Shudehill Mill: The Archaeology of Manchester's First Steampowered Cotton Mill', Industrial Archaeology Review 38.2, 98-118.

Miller I \& Wild C, 2007, A \& G Murray and the Cotton Mills of Ancoats. Lancaster Imprints 13. Oxford Archaeology North.

Nevell M, 2008, Manchester. The Hidden History. (Stroud: History Press, 2008), 82-92.

Nevell M, 2010, 'Excavating the Cotton Mill. Towards a Research Framework for the BelowGround Remains of the Textile Industry', in Belford P, Palmer M \& White R, Footprints of Industry. Papers from the 300 th anniversary conference at Coalbrookdale, 3-7 June 2009. BAR British Series 523, 153-68.

Nevell M, 2016, 'Evolving Approaches for Recording the Textile Mill', Industrial Archaeology Review 38.2, 83-84.

Nevell M \& Roberts J, 2003, The Park Bridge Ironworks and the Archaeology of the Wrought Iron Industry in North West England. Volume 3 in the Archaeology of Tameside Series. Tameside MBC and UMAU.

Nevell M, Roberts J \& Champness B, 2004, 'Excavating the Iconic: The Rediscovery of the Fairbottom Bobs Colliery Pumping Engine', Industrial Archaeology Review 26.2, 83-94.

Nuvolari A, Verspagen B \& Tunzelmann N von, 2011, The early diffusion of the steam engine in Britain, 1700-1800: a reappraisal', Cliometrica 5, 291-321. 
Perrett D, 'The Surviving Newcomen Engines', Links 221 (Newsletter of the Newcomen Society), March 2012, 10-11.

Redhead N, 2011, 'Archaeological Investigations of Workers' Housing in Manchester', North West Labour History 35, 53-57.

Rose M E with Falconer K \& Holder J, 2011, Ancoats. Cradle of industrialization. Swindon. English Heritage.

Tann J, (ed.), 1981, The Selected Papers of Boulton \& Watt, Vol. 1: The Engines Partnership, 1775-1825. London.

Williams M with Farnie D, 1992, Cotton Mills in Greater Manchester. Lancaster: Carnegie Publishing Ltd. 